\title{
Synchrotron radiation-based experimental determination of the optimal energy for cell radiotoxicity enhancement following photoelectric effect on stable iodinated compounds
}

\author{
S Corde', A Joubert', JF Adam', AM Charvet', JF Le Bas', ${ }^{1,2}$ F Estève ${ }^{1,2}$, H Elleaume ${ }^{1,3}$ and J Balosso ${ }^{*, 1,4}$ \\ 'INSERM U647 'Rayonnement Synchrotron et Recherche Médicale', Université Joseph Fourier \& ID 17 Biomedical Beamline of European Synchrotron \\ Radiation Facility, CHU A Michallon, BP 217, 38043 Grenoble Cedex 09, France; ' Unité IRM, service de Neuroradiologie, CHU A Michallon, BP 217, \\ 38043 Grenoble Cedex 09, France; ' IFR no. I 'RMN biomédicale, de la cellule à l'homme', CHU A Michallon, BP 217, 38043 Grenoble Cedex 09, \\ France; ${ }^{4}$ Département de Cancérologie et d'Hématologie, Service de Radiothérapie, CHU A Michallon, BP 217, 38043 Grenoble Cedex 09 , France
}

This study was designed to experimentally evaluate the optimal X-ray energy for increasing the radiation energy absorbed in tumours loaded with iodinated compounds, using the photoelectric effect. SQ20B human cells were irradiated with synchrotron monochromatic beam tuned at 32.8, 33.5, 50 and $70 \mathrm{keV}$. Two cell treatments were compared to the control: cells suspended in $10 \mathrm{mg} \mathrm{ml}^{-1}$ of iodine radiological contrast agent or cells pre-exposed with $10 \mu \mathrm{M}$ of iodo-desoxyuridine (IUdR) for $48 \mathrm{~h}$. Our radiobiological end point was clonogenic cell survival. Cells irradiated with both iodine compounds exhibited a radiation sensitisation enhancement. Moreover, it was energy dependent, with a maximum at $50 \mathrm{keV}$. At this energy, the sensitisation calculated at $10 \%$ survival was equal to 2.03 for cells suspended in iodinated contrast agent and 2.60 for IUdR. Cells pretreated with IUdR had higher sensitisation factors over the energy range than for those suspended in iodine contrast agent. Also, their survival curves presented no shoulder, suggesting complex lethal damages from Auger electrons. Our results confirm the existence of the $50 \mathrm{keV}$ energy optimum for a binary therapeutic irradiation based on the presence of stable iodine in tumours and an external irradiation. Monochromatic synchrotron radiotherapy concept is hence proposed for increasing the differential effect between healthy and cancerous tissue irradiation.

British Journal of Cancer (2004) 9I, 544-55।. doi:I0.1038/sj.bjc.660195 I www.bjcancer.com

Published online 13 July 2004

(c) 2004 Cancer Research UK

Keywords: monochromatic synchrotron radiation; radiotherapy; iodine; radiation dose enhancement

Megavoltage radiation beams are nowadays widely used for anticancer radiotherapy. High-energy linear accelerators allow highly penetrating radiation to treat targeted volumes with a better sparing of superficial healthy tissues. Moreover, in this range of energies $(1-25 \mathrm{MeV})$, photons beams mainly interact with living matter by Compton scattering processes, almost independent of the composition of the traversed material. Thus, a highly homogeneous dose distribution is achievable in the human body and predicted accurately by Monte-Carlo based three-dimensional treatment planning systems.

Lower energy beams are preferred for medical imaging. Kilovoltage X-ray beams are used for the production of radiological images and the predominant physical process in high-density materials is the photoelectric effect, which is strongly Z-dependent. Hence, attenuation in bone is far higher than for soft tissues, and the radiological contrast rely on photoelectric processes. The spectra of these X-ray tube beams vary between 10 and $250 \mathrm{keV}$.

Healthy tissue tolerance remains the major limiting factor of anticancer radiotherapy and techniques are investigated to

*Correspondence: Professor J Balosso; E-mail: JBalosso@chu-grenoble.fr Received I 4 January 2004; revised 6 April 2004; accepted 27 April 2004; published online 13 July 2004 enhance the local control of tumours by increasing the absorbed X-ray dose, while preserving more efficiently the healthy surrounding tissues.

Dual modalities like Boron Neutron Capture Therapy (BNCT) propose enhancing the neutron capture reaction cross-sections in a stable boron-loaded tumour (Barth et al, 1990). Toxicity of the irradiation is increased in the tumour by the production of high linear energy transfer alpha and lithium ion particles. The neutron dose enhancement is highly correlated to the boron concentration present inside the tumour at the time of the irradiation. The most limiting factor remains the boron concentrations achievable (Soloway et al, 1994; Coderre et al, 1998) and their in vivo measurement (Verbakel and Stecher-Rasmussen, 2001). Nevertheless, clinical trials are underway for patients with high-grade brain gliomas, which remains a hardly curable tumour type.

For photon beams, a bimodal approach known as 'Photon Activation Therapy' has been proposed in the early 1970s (TisljarLentulis et al, 1973; Tisljar-Lentulis and Feinendegen, 1977). High$\mathrm{Z}$ heteroatoms in DNA could be used for increasing kilovoltage Xray killing efficiency, by generating photoelectric events. Ionised heavy atoms then reorganise and emit low-energy Auger electrons cascades, able to damage DNA because of their nuclear localisation. In a less specific way, Norman et al developed another 
approach: the use of a conventional kilovoltage scanner to treat iodine-loaded tumours (Iwamoto et al, 1990; Rose et al, 1999). By increasing the tumour density and focussing a kilovoltage beam on it, interaction cross-sections are improved in the tumour only, due to the photoelectric effect, and the dose distribution is concentrated inside the tumour (Solberg et al, 1992a, 1995; Mesa et al, 1999). Moreover, tumour imaging is achievable during treatment with this scanner. The lack of such a modality is actually a weakness of current megavoltage radiotherapy treatments. The physical properties of high-energy beams allow good dose distribution characteristics but do not allow good imaging yet.

What would be the optimal X-ray energy, if any, for irradiating tumours loaded with high- $Z$ elements? Considering a heavy element introduced to living matter as isolated atoms, irradiation with an energy just above the K-edge appears conceptually as the best option to enhance energy deposition by the contribution of Auger electrons events. This concept has been tested with iodine and other heavy atoms, irradiated with either monochromatic radioactive sources (Nath et al, 1990), or synchrotron X-rays (Laster et al, 1993; Hieda et al, 1996). Laster et al obtained convincing results with iodine incorporated into DNA as 5-iodo2 '-deoxyuridine (IUdR). Others, as Solberg et al (1992a) and Karnas et al (1999) suggested, by calculation, that the optimal energy should be far above the iodine K-edge and around $50 \mathrm{keV}$ because it corresponds to the energy level where the difference between the mass energy absorption coefficients of water and iodine is the largest. Therefore, two different concepts were to be considered: the first one based on the occurrence of particular events; the second one taking into account the difference in absorption capacity of the living matter with and without the presence of a certain concentration of iodine, whatever the structure imbedding it.

As pointed out by Karnas et al (1999) and Solberg et al (1992b), monochromatic X-rays produced by a synchrotron should be the best tool for verifying these hypotheses. Powerful third generation synchrotrons are now available to deliver broad X-ray beams $(10-100 \mathrm{keV})$, brilliant enough for using monochromators and able to precisely select the desired X-rays energy. At the European Synchrotron Radiation Facility (ESRF, Grenoble, France), the ID17 beamline is dedicated to medical applications of synchrotron radiation (Thomlinson et al, 2000) and is designed for human in vivo experiments (Elleaume et al, 1999, 2000a).

In this paper we report the experimental demonstration of the existence of an optimal value of the enhancement ratio produced by the presence of iodine compounds. We studied its variation along the energy spectrum from 30 to $70 \mathrm{keV}$ in two different experimental settings: extracellular iodine from contrast agent and iodine incorporated into DNA as IUdR.

\section{METHODS AND MATERIALS}

\section{Chemicals}

5-iodo-2'-deoxyuridine was provided by Lausanne University Hospital Pharmacy (Switzerland) as lyophilised powder. Iodinated radiographic contrast agent used for extracellular iodine was Iomeron ${ }^{\mathbb{R}}$ (Bracco, Milano, Italy), which is a nonionic, monomeric iodine compound containing $350 \mathrm{mg}$ of iodine per $\mathrm{ml}$ of solution.

\section{Cell line}

The SQ20B cell line was derived from a human head and neck squamous carcinoma (Weichselbaum et al, 1986) and was obtained from William K Dahlberg (Dr JB Little Laboratory, Harvard School of Public Health). This cell line is commonly used for radiobiological research, and has been handled as previously described (Corde et al, 2002). The SQ20B doubling time is $21 \mathrm{~h}$.

\section{Cell culture technique, colony-forming assay}

Cells were seeded and grown as monolayer in plastic tissue culture disposable flasks (Falcon) with $0.4 \mathrm{ml} \mathrm{cm}^{-2}$ Dulbecco's modified Eagle's minimum medium (Gibco-BRL), added with $10 \%$ foetal calf serum (Gibco-BRL), penicillin and streptomycin (Gibco-BRL). Cells were grown at $37^{\circ} \mathrm{C}$ in a humidified atmosphere of $5 \% \mathrm{CO}_{2}$ in air.

When IUdR was used, $48 \mathrm{~h}$ before irradiation, cell cultures were incubated with $10 \mu \mathrm{m} \mathrm{IUdR}\left(1.3 \mathrm{mg}\right.$ iodine $\left.\mathrm{l}^{-1}\right)$, diluted in fresh medium. Before irradiation, cells were trypsinised and experiments were carried out with the cell suspension in $2 \mathrm{ml}$ sterile cryotubes (Merck Eurolab) with or without Iomeron ${ }^{\circledR}\left(10 \mathrm{~g}_{\text {iodine }} \mathrm{l}^{-1}\right)$ added to the culture medium, according to the experimental protocol.

Three independent experiments have been carried out and averaged. After each irradiation, triplicate low-density subcultures of the cells were established in $\varnothing 100 \mathrm{~mm}$ Petri dishes for colonyforming assay. Colonies were fixed and stained with violet crystal oxalate (Merck Eurolab) after 15 days of cell growing.

\section{Irradiation procedure}

Irradiation was carried out at room temperature in aerobic conditions at the ESRF medical beamline (ID17) (Elleaume et al, 1999). Cells were irradiated as suspension in horizontal continuously rotating cryotubes $(2 \mathrm{ml}, 10 \mathrm{~mm}$ in diameter), vertically translated up-and-down through a $500-\mu \mathrm{m}$-thick X-ray beam providing a dose rate calculated in water of about $0.5 \mathrm{~Gy} \mathrm{~s}^{-1}$. Dose calibrations were performed using a cylindrical ion chamber (PTW 31002) coupled with a Unidos ${ }^{\mathbb{R}}$ electrometer. They were crosschecked with a high-purity Germanium detector (Eurisys Mesures ${ }^{\mathbb{R}}$, Lingolsheim, France). Real-time control of delivered doses was provided by a $10 \mathrm{~cm}$ long nitrogen filled ion chamber, continuously present in the beam.

Energies were tuned with an accuracy of $\pm 100 \mathrm{eV}$. The dose rate was equal for all the tested energies, which were $32.8,33.5,50$ and $70 \mathrm{keV}$. We point out that the K-edge of iodine is $33.169 \mathrm{keV}$. This setting was obtained with an $\operatorname{Si}(111)$ fixed-exit monochromator, designed for computed tomography with synchrotron radiation as previously described (Suortti et al, 2000; Corde et al, 2002). The ESRF storage ring was operating in its 'uniform mode', providing a storage ring current decreasing from 200 to $170 \mathrm{~mA}$ with a lifetime of $60 \mathrm{~h}$.

\section{Data analysis}

Colonies with more than 50 cells were counted using digital images of Petri dishes containing fixed and stained clones, associated with a computer assisted image analysis system (Samba Technologies, Meylan, France) as previously described (Biston et al, 2003), which allows to avoid subjective bias in the procedure. (LQ):

Experimental data were fitted with the linear quadratic model

$$
S=\exp \left(-\alpha D-\beta D^{2}\right)
$$

where $S$ is the survival probability, $D$ the radiation dose (Gy), $\alpha$ and $\beta$ are the fit parameters $\left(\mathrm{Gy}^{-1}\right.$ and $\mathrm{Gy}^{-2}$ respectively).

\section{Enhancement ratio}

We used two different ratios to measure the dose modifications produced by the iodine.

The sensitisation enhancement ratio at ' $S \%$ ' of survival, $\mathrm{SER}_{\mathrm{s} \%}$ was calculated from the experimental cell survival curves and defined as the ratio of doses (sensitised to control) that yielded a 
given cell survival level of $S \%$ :

$$
\mathrm{SER}_{\mathrm{s} \%}=\frac{D_{S}^{\text {control }}}{D_{S}^{\exp }}
$$

The theoretical expected dose enhancement ratio, DER, was calculated from the variation of the mass energy-absorption coefficient of the target due to the presence of iodine:

$$
\mathrm{DER}=\frac{\left(\frac{\mu_{\mathrm{en}}}{\rho}\right)_{E}^{\text {water+iodine }}}{\left(\frac{\mu_{\mathrm{en}}}{\rho}\right)_{E}^{\text {water }}}=\frac{w_{\mathrm{I}}\left(\frac{\mu_{\mathrm{en}}}{\rho}\right)_{E}^{\text {iodine }}+\left(1-w_{\mathrm{I}}\right)\left(\frac{\mu_{\mathrm{en}}}{\rho}\right)_{E}^{\text {water }}}{\left(\frac{\mu_{\mathrm{en}}}{\rho}\right)_{E}^{\text {water }}}
$$

where

$$
\left(\frac{\mu_{\mathrm{en}}}{\rho}\right)_{E}
$$

is the mass energy absorption coefficient for the considered compound irradiated with monochromatic X-rays beam (energy: $E$ ) and $w_{\mathrm{I}}$ is the fraction by weight of iodine in the mixture.

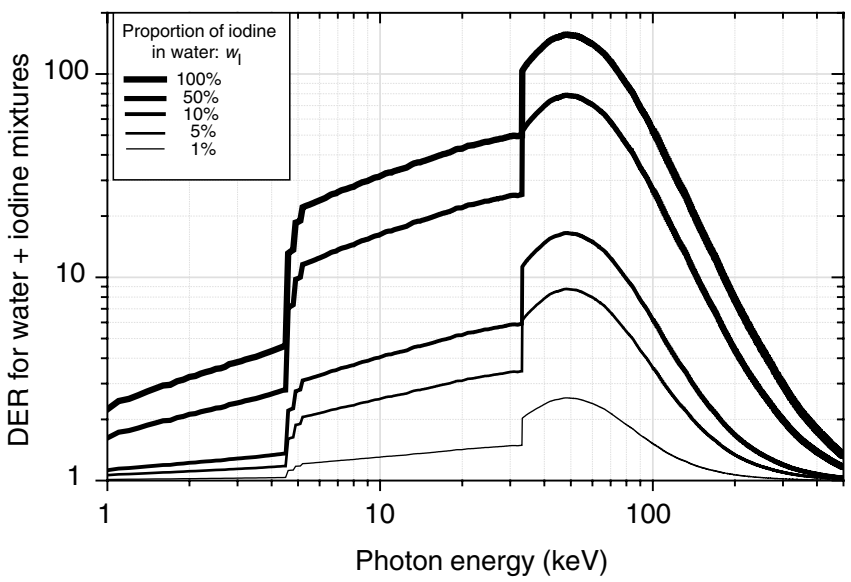

Figure I Energy dependence of the theoretical dose-enhancement ratio for several iodine aqueous mixtures (from bottom to top, the mass proportion of iodine in water, $w_{1}$ is ranging from 0.01 to I).

\section{RESULTS}

\section{Energy dependence of the DER for different iodine} concentrations in water

DER variation with photon energy has been represented in Figure 1 from Hubble physical data references (Hubbell and Seltzer, 1997). This variation is a bell-shaped curve having its maximum around $50 \mathrm{keV}$. The maximum DER is strikingly increased when the iodine concentration in water is rising up to $100 \%$, reaching about 160 . The range of energies yielding such a sharp variation is rather narrow from the K-edge of iodine $(33 \mathrm{keV})$ up to about $80 \mathrm{keV}$.

\section{Experimental energy dependence of the SER for cells irradiated with $10 \mathrm{mg} \mathrm{ml}^{-1}$ of extracellular iodine in medium}

Survival curves of SQ20B cells are displayed in Figures 2A-C, showing the modifications of the dose-effect relationship for synchrotron radiation of different energies with or without $10 \mathrm{mg} \mathrm{ml}^{-1}$ of iodine introduced as Iomeron ${ }^{\circledR}$. These experimental results have been obtained with a constant dose rate whatever the energy level. It appears that the radiosensitisation is energy dependent.

The comparison of experimental $\mathrm{SER}_{10 \%}$ with the calculated DER, according to the energy, is shown in Figure 3. The variation in the behaviour of both parameters with energy is similar with the same apparent maximum at $50 \mathrm{keV}$ but experimental results are constantly lower than predicted. The experimental $\mathrm{SER}_{10 \%}$ increases slightly when the energy goes through the iodine K-edge (from 1.05 to 1.23), but reaches its maximum for $50 \mathrm{keV}$ (1.95) and decreases again for $70 \mathrm{keV}$ as the theory predicts.

\section{Experimental energy dependence of the SER for cells irradiated with $10 \mu \mathrm{M}$ of iodine incorporated in DNA as IUdR}

The same experiment was performed with iodine incorporated into the cell nucleus as iodinated nucleotide by exposure to $10 \mu \mathrm{M} \mathrm{IUdR}$ during $48 \mathrm{~h}$ followed by irradiation at different energy levels. Once again, we observed a cell sensitivity energy dependence, for the same dose rate of monochromatic irradiation, as shown in Figures $4 \mathrm{~A}-\mathrm{C}$. Similarly, $50 \mathrm{keV}$ is the energy yielding the maximum cytotoxic effect. The experimental $\mathrm{SER}_{10 \%}$ obtained is 2.6 for
A

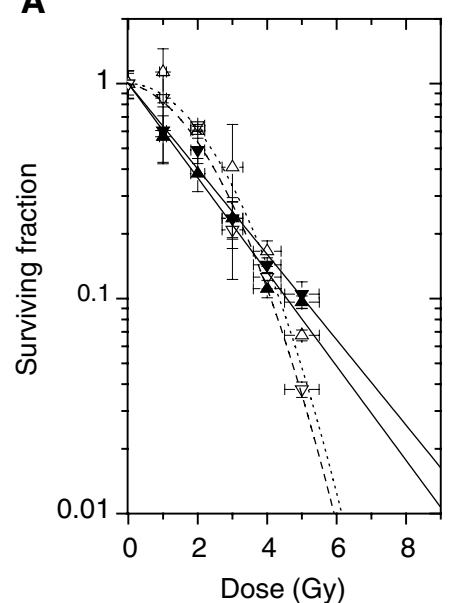

B

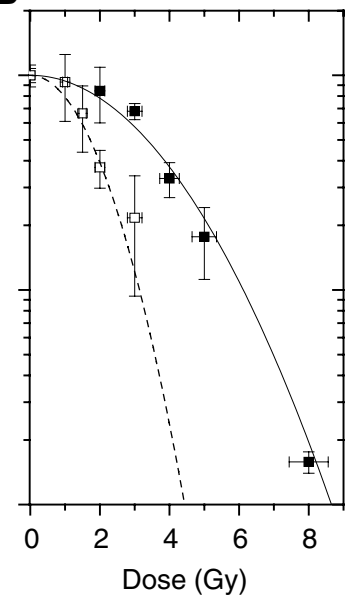

C

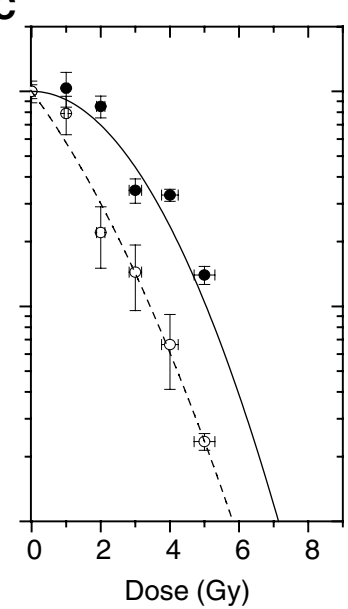

Figure 2 Survival curves of SQ20B cells irradiated with (open symbols) or without (closed symbols) $10 \mathrm{mg} \mathrm{ml}^{-1}$ iodine incorporated as contrast agent in medium, for the energies: (A) around iodine K-edge: $32.8 \mathrm{keV}$ (triangles) and $33.5 \mathrm{keV}$ (reversed triangles); (B) $50 \mathrm{keV}$ (squares); (C) $70 \mathrm{keV}$ (circles). Each survival curve fit is derived from the dose and surviving fraction data (triplicate experiments). 
$50 \mathrm{keV}$, and the difference below $v s$ above the K-edge of the iodine is fairly reduced, the values are, respectively, 1.25 and 1.64 .

\section{Comparison of the effects of both iodine compounds}

Figure 5 compares the $\mathrm{SER}_{10 \%}$ obtained with SQ20B cells irradiated at different energies with either $10 \mathrm{mg} \mathrm{ml}^{-1}$ extracellular iodine or intracellular iodine incorporated into the nucleus as IUdR. For the same survival level, namely $10 \%$, the intracellular situation of iodine proved to be more efficient than the extracellular case except for the highest energy of $70 \mathrm{keV}$.

Interestingly, the comparison of survival curves from Figure 2 and 4 shows a more deeply altered shape for intracellular iodine than for the extracellular iodine. The initial shoulder is strongly reduced giving a high-TEL-radiation-like shape for intracellular iodine. As an illustration, Figure 6 shows the variation of the $\mathrm{SER}_{\mathrm{s} \%}$, according to the survival level, measured at $50 \mathrm{keV}$. A striking difference is observed between both iodine situations. For

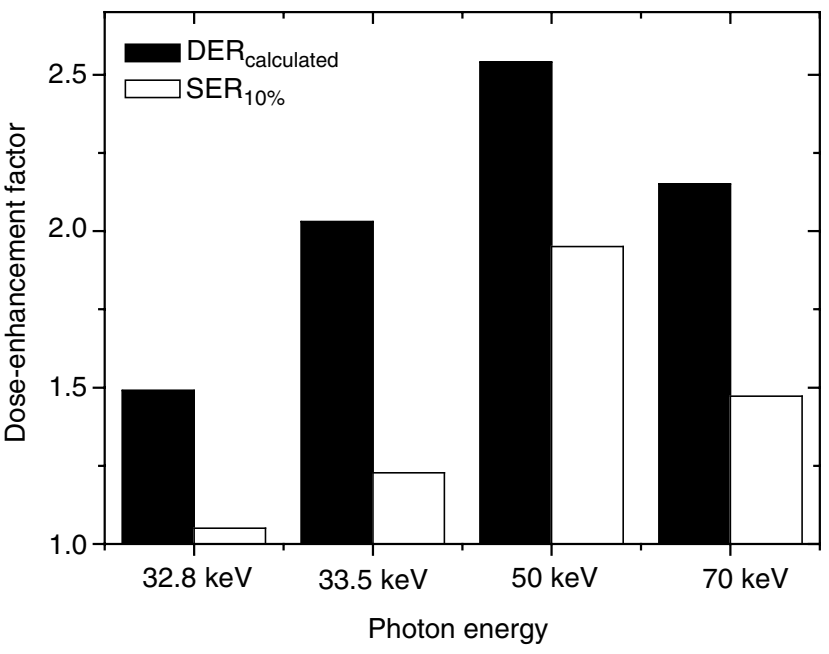

Figure 3 Comparison of the energy dependence of the calculated doseenhancement factor (DER) with the measured one at $10 \%$ survival level $\left(\mathrm{SER}_{10 \%}\right)$, for $10 \mathrm{mg} \mathrm{ml}^{-1}$ of extracellular iodine. intracellular iodine, the sensitisation enhancement ratio increases from 2.6 for a survival rate of $10 \%$ up to almost 10 for $90 \%$ survival. For the extracellular iodine, the sensitisation enhancement ratio is almost constant around 2 .

\section{DISCUSSION}

The sensitivity of SQ20B cells to kilovoltage X-ray beams is enhanced in the presence of the iodine compounds, whatever its subcellular localisation. This enhancement depends upon the choice of the X-ray energy beam, as predicted by the theoretical DER curves (Figure 1).

\section{Iodine contrast agent as radiation sensitiser}

When extracellular iodinated contrast agent was used, experimental values of the enhancement ratio, estimated at $10 \%$ of the surviving fraction from the linear-quadratic interpolation of the

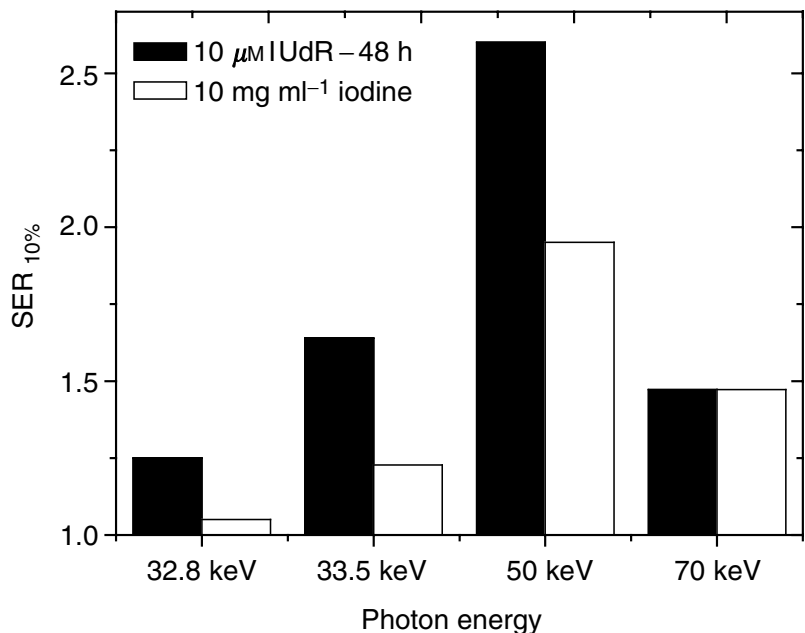

Figure 5 Comparison of the energy dependence of the sensitization enhancement ratio $\left(\mathrm{SER}_{10 \%}\right)$ for cells pretreated with $10 \mu \mathrm{M} I \mathrm{IdR}$ for $48 \mathrm{~h}$ or irradiated with $10 \mathrm{mg} \mathrm{m}^{-1}$ of iodine incorporated in their medium as contrast agent.
A

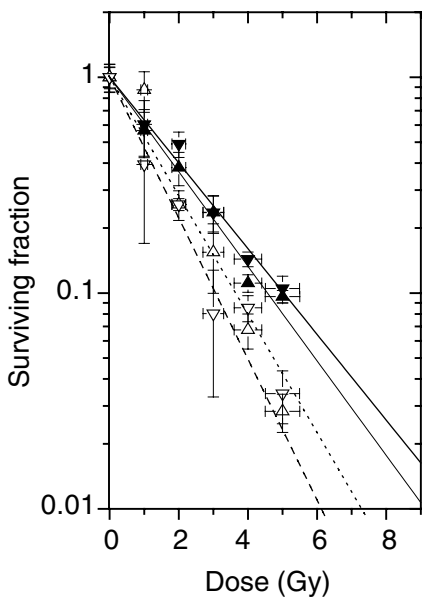

B

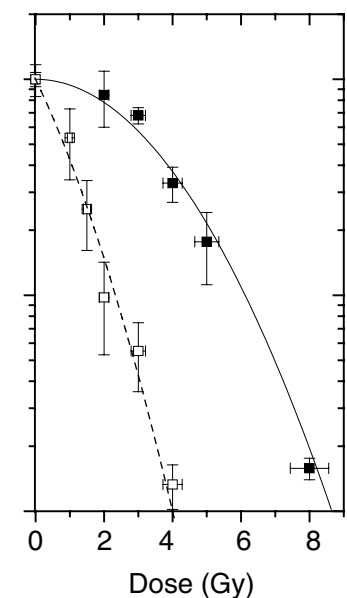

C

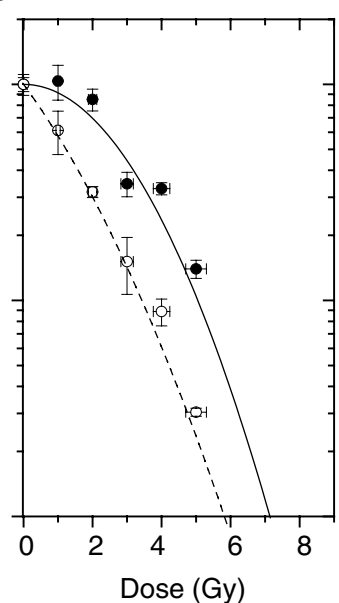

Figure 4 Survival curves of SQ20B cells irradiated with (open symbols) or without (closed symbols) a 48-h pre-exposure to I0 $\mu \mathrm{M} I \mathrm{IUR}$, for the energies: (A) around iodine K-edge: $32.8 \mathrm{keV}$ (triangle) and $33.5 \mathrm{keV}$ (reversed triangle); (B) $50 \mathrm{keV}$ (square); (c) $70 \mathrm{keV}$ (circle). Each survival curve fit is derived from the dose and surviving fraction data (triplicate experiments). 


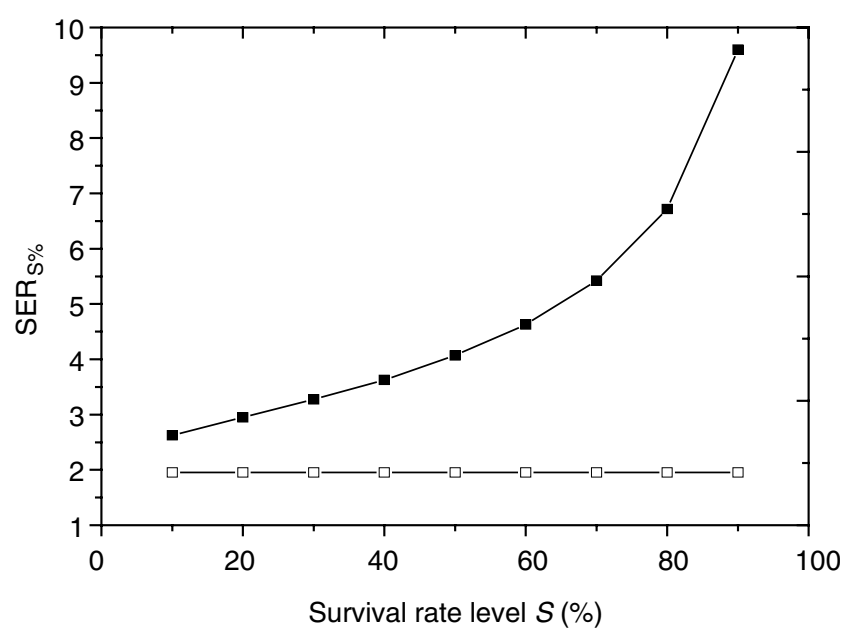

Figure 6 Comparison of the survival level dependence for the calculation of the experimental factor $\mathrm{SER}_{\mathrm{S} \%}$ for cells irradiated at $50 \mathrm{keV}$ either with a $48 \mathrm{~h}$ pre-exposure to $10 \mu \mathrm{M} I U d R$ (closed symbols) or with $10 \mathrm{mg} \mathrm{ml}^{-1}$ iodine incorporated in the medium via a contrast agent (open symbols).

survival curves, was systematically inferior to the DER by a factor varying between $23 \%(50 \mathrm{keV})$ to $40 \%(33.5 \mathrm{keV})$.

Such differences between the calculated and the experimental enhancement ratio could be explained by different factors:

(i) Since not all energy deposited results in cell killing, the theoretical dose enhancement ratio will always overestimate in vitro or in vivo measurements.

(ii) The experimental working conditions are arbitrary (choice of the cell line, geometry of the setup, cell density during irradiation).

(iii) Calculation of the theoretical factor does not take into account the experimental geometry: a physical autoabsorption of the photoelectrons by the medium itself and as a consequence less radiation dose seen by the cells in suspension in their medium could be taken into consideration by finer simulations.

(iv) Finally, the survival rate level chosen for the comparison is of prime importance as suggested in Figure 6.

Nevertheless, the shape of both the enhancement ratio variations are consistent, with an experimental maximum at $50 \mathrm{keV}$ and a minimum just below the iodine $\mathrm{K}$-absorption edge (Figure 3). Moreover, this enhanced radiosensitivity is concentration dependent, as published elsewhere (Estève et al, 2002).

We interpret the lethal effect enhancement observed as closely linked to photoelectric interaction on the high- $Z$ atoms present in the vicinity of the SQ20B cells (Callisen et al, 1979). As studied by Matsudaira et al (1980), the use of more energetic radiation, such as $\gamma$ for instance, would not imply similar results. With these energies comparable with the ones used in radiotherapy, Compton scattering is the major physical interaction and does not vary sufficiently with the matter composition for giving probing enhancement factors (Robar et al, 2002). Matsudaira et al (1980) demonstrated with a $200 \mathrm{kV}_{\mathrm{p}}$ polychromatic (p) X-rays tube that $5 \%$ of iodine in the cell growing medium modified cellular response to the irradiation, but no effect was shown with irradiation from ${ }^{60} \mathrm{Co}$.

We extrapolated their survival curve data and estimated that the $\mathrm{SER}_{10 \%}$ factor was equal to 2.24 for $50 \mathrm{mg} \mathrm{ml}^{-1}$ of iodine and $200 \mathrm{kV}_{\mathrm{p}}$ irradiation. Dawson et al (1987) have found similar results with an $\mathrm{SER}_{10 \%}$ estimated from their data to be around 1.8 for $20 \mathrm{mg} \mathrm{ml}^{-1}$ of iodine and $250 \mathrm{kV}_{\mathrm{p}}$ irradiation. Interpolation of their data to $10 \mathrm{mg} \mathrm{ml}^{-1}$ of iodine would have led to a sensitisation enhancement ratio of 1.3. This factor has been increased to 2.25 by using a lower energy X-ray beam of $140 \mathrm{kV}_{\mathrm{p}}$ (Iwamoto et al, 1987; Solberg et al, 1992a). Nevertheless, this last value has not been calculated from survival curves data, but from micronuclei formation in cells postirradiation.

These experimental demonstrations of the radiotoxicity enhancement of low- and medium-energy X-rays due to the presence of iodinated contrast agents had some consequences in radiological diagnosis, mainly because of the fear of mutagenic effects postexamination (Adams et al, 1977; Norman et al, 1978, 2001). Nevertheless, the X-ray doses implied in such examinations are not comparable with the therapeutic ones.

Based on these results, a brand new radiotherapy technique called CTRx for computed tomography radiotherapy was put forward by Norman and collaborators. They propose using a classical scanner (voltage $140 \mathrm{kV}_{\mathrm{p}}$ ) slightly modified for allowing field collimation, adjustable to tumour sizes. The aim of the technique is to obtain sharp isodoses around the tumour, using both the photoelectric effect on the high- $Z$ element present in the tumour and the circular irradiation ballistic (Mesa et al, 1999). Phase I clinical trial was published for treatment of patients with metastatic brain tumours, loaded with iodinated contrast agents, and demonstrated the feasibility of this technique (Rose et al, 1999). The dose-enhancement effect is hence theoretically optimised with $140 \mathrm{kV}_{\mathrm{p}} \mathrm{X}$-rays beams when compared with $10 \mathrm{MV}$, and, interestingly enough even in cases of stereotactic irradiation.

However, polychromatic conventional X-ray tubes do not lead to an optimum energy deposition inside the iodine-loaded tumour (X-ray spectrum hardening with depth). Synchrotron X-rays beam should allow the choice of the optimal X-ray energy for energy absorption enhancement inside the iodinated tumour compared with healthy nonloaded tissues (Solberg et al, 1992b).

Our results show that this optimal energy does exist and according to our calculations, its value is around $50 \mathrm{keV}$. For this particular energy, the $\mathrm{SER}_{10 \%}$ measured on our cell line is 2.03 for $10 \mathrm{mg} \mathrm{ml}^{-1}$ of iodine incorporated as contrast agent in the medium. This sensitisation value appears to have the same order of magnitude for monochromatic beam in comparison with the results quoted above with polychromatic beams. Nevertheless, such comparisons have to be made carefully and are always difficult when different cell lines are considered. It should be stressed that SQ20B cell line is particularly radioresistant and nonapoptotic (Brachman et al, 1993).

Another advantage of the synchrotron radiation beam, for this bimodal approach, is the imaging scanner tool, which was developed on the ESRF ID17 medical beamline (Elleaume et al, $2000 \mathrm{~b}, 2002)$. It allows the in vivo measurement of absolute tumoral iodine concentrations (Le Duc et al, 2000), which is an essential parameter for planning the doses to be delivered. This advantage is not available with other bimodal approaches: neither with conventional scanners due to beam hardening nor for BNCT as previously mentioned. This could be a valid argument for considering this technique for clinical trial evaluation.

\section{Iodine incorporated into DNA as IUdR: subcellular and energetic optimisations}

5 -iodo-2'-deoxyuridine was used in this study to optimise the subcellular localisation of iodine compounds. 5-iodo-2'-deoxyuridine does not remain extracellular as contrast agents, but directly substitutes DNA thymidine base, and is hence incorporated inside the DNA morphology during its replication in cycling cells (Pomplun and Terrissol 1994). This compound is known to sensitise mammalian cells to damage induced by ionizing radiation, both in vitro and in vivo. The underlying sensitisation mechanism is not yet fully understood but could rely on alteration of the DNA structure (Iliakis and Kurtzman, 1989) or a decrease in 
cell reparability (Wang and Iliakis, 1992; Wang et al, 1994). As this compound requires a cellular proliferation activity, it has the property to target tumours having high proliferation rates.

The photonic activation of stable iodine atoms, incorporated in DNA with IUdR, was first proposed by Fairchild et al (1982). They calculated a sensitisation factor comprised between 1.5 and 3 depending on the percentage of thymidine replacement. This technique avoids the drawbacks of IUdR labelled with Auger emitters radioisotopes, which are also toxic for healthy fastgrowing tissues such as the bone marrow.

Whereas clinical use of IUdR in association with megavoltage Xrays beams brought to reserved results (Epstein et al, 1992), photon activation therapy proposed by Fairchild and Bond (1984) was based not only on IUdRs use but also on the idea of an energetic optimisation of the X-ray beam too. Photoelectric absorption discontinuities of the isolated heavy atoms lead to the conclusion that the energy just above the K-absorption edge of iodine was the optimal one. Laster et al (1993) demonstrated, for this particular energy, that the dose necessary to decrease the surviving V79 cells fraction to $10 \%$ was three times less for cells pre-exposed to $6 \mu \mathrm{M}$ IUdR for $14 \mathrm{~h}$ ( $16 \%$ substitution) than for the untreated cells. This value decreased to 1.4 -fold less when synchrotron X-rays energy was just below the iodine K-edge. These are the most satisfying results yet, among a series of similar works, which had common objectives but used different experimental methods. A sensitisation ratio equal to 1.8 has been observed by Shinohara et al (1996) with 20\% thymidine bases substituted by iodine from IUdR and a $\gamma$-irradiation from ${ }^{60} \mathrm{Co}$. Another study with ${ }^{137} \mathrm{Cs}$ irradiation and similar iodine content gave comparable results (Fairchild et al, 1985). This factor was found to be equal to 1.5 by Nath et al (1987) with $250 \mathrm{kVp}$ $\mathrm{X}$-rays.

The choice of the optimal X-ray energy for irradiating IUdR pretreated cells is investigated in the present work, similarly to Karnas et al (1999, 2001a). Theoretical calculation of the DER relative to the presence of $10 \mu \mathrm{M}$ of IUdR during the irradiation in water would be negligible, very close to 1 , except if this factor is calculated at the microscopic level, as suggested by Karnas et al In that case, a DER comprised between 2 and 3 for $50 \mathrm{keV}$ irradiation is expected for a $10-30 \%$ thymidine base replacement by iodine. Other authors have reported comparable measured DNA iodine contents for exposure of exponentially growing cells. Hence, for a $10 \mu \mathrm{m}$ IUdR during a double cell cycling time $(48 \mathrm{~h})$, a thymidine substitution ranging between 10 and $20 \%$ is expected (Laster et al, 1993).

Consequently, our experimental results are in good agreement with the calculations made by Karnas et al (1999). Due to the lack of available synchrotron sources, adjustable monochromatic beams were not used to validate their calculation, but $\mathrm{CHO}$ cells exposed to $10 \mu \mathrm{M}$ IUdR for 3 days and irradiated with medium energy X-ray tube $\left(100 \mathrm{kV}_{\mathrm{p}}\right)$ exhibited $\mathrm{SER}_{1 \%}$ of 1.8 vs 1.4 for lowenergy spectrum $\left(30 \mathrm{kV}_{\mathrm{p}}\right)$. By filtrating the $100 \mathrm{kV}_{\mathrm{p}}$ beam with tungsten, $\mathrm{SER}_{1 \%}$ reached a value of 2.7 , corresponding to a thymidine substitution by iodine of $18 \%$.

With a monochromatic beam, SER $_{10 \%}$ for SQ20B cells preexposed for $48 \mathrm{~h}$ to $10 \mu \mathrm{M}$ IUdR was found to be equal to 2.62 at $50 \mathrm{keV}$. This energy corresponds to the experimental maximum of radiosensitisation. Interestingly, around the K-edge of iodine, $\mathrm{SER}_{10 \%}$ slightly increases by crossing the edge (from 1.25 to 1.64 ) but our enhancement ratios remain low in comparison with some other published data (Laster et al, 1993). Moreover, energies around the K-edge are experimentally found not to be optimal for increasing the differential effect between treated and untreated cells.

Owing to the energy dependence of the sensitisation found for cells pretreated with IUdR, it is more likely due to the photoelectric effect than to an intrinsic sensitisation action of IUdR, for which an energy dependence could hardly be expected.

\section{Comparison of the effects of both iodine compounds}

Pre-exposure of cells to $10 \mu \mathrm{M} \mathrm{IUdR}$ for $48 \mathrm{~h}$ leads to greater sensitisation enhancement ratios than the presence of $10 \mathrm{mg} \mathrm{ml}^{-1}$ of iodine as contrast agent in the medium (Figure 5). 5-iodo- $2^{\prime}$ deoxyuridine is $30 \%$ more efficient at 33.5 and $50 \mathrm{keV}, 20 \%$ more at $32.8 \mathrm{keV}$ and sensitisation ratios appear to be the same at $70 \mathrm{keV}$. Above the K-edge of iodine, photoelectrons from the $\mathrm{K}$ shell are extracted with a kinetic energy of $300,18.8$ and $36.8 \mathrm{keV}$ for $33.5,50$ and $70 \mathrm{keV}$ excitation energies, respectively. Reported to the nucleus and cellular dimensions, the range of photoelectrons emitted by iodine atoms placed inside the DNA is then less critical for the highest energies studied. The biological efficiency of photon activated IUdR with regard to the extracellular iodine could be explained by damages produced directly inside the DNA by Auger electrons. These low-energy electron cascades are known to be biologically efficient and extremely toxic, but only if generated in the nucleus or preferably in the DNA (Commerford et al, 1980; Faraggi et al, 1994; van Dieren et al, 1996).

The effect of Auger electron cascades for IUdR can be deduced by analyzing the shape of survival curves (Figures 4 and 6). The absence of a shoulder indicates a defect in repair of DNA damages, which are supposed to be more complex. On the contrary, survival curves for iodine incorporated as contrast agent do not show any loss of shoulder and seem to indicate a simple creation of an extra number of both single strand breaks (SSB) and double-strand breaks (DSB). For IUdR data, this leads to an extreme dependence of the SER factor with the choice of the survival level $S \%$ used for the calculation. The $\mathrm{SER}_{90 \%}$ reaches a value of 9.5 around $90 \%$ of cell survival rate, which could be worth considering for a fractionated irradiation with low dose per fraction. On the contrary, the ratios remain similar for iodinated contrast agent, whatever the survival level chosen. The survival curves exhibit then low-LET shapes, indicating that in both approaches, completely different biophysical and molecular damages are generated inside the DNA.

Some reserve has been expressed in the literature concerning the potential clinical use of externally synchrotron-activated stable IUdR (Miller et al, 1987a, b; Humm, 1988a; Humm and Charlton 1988b). Our encouraging results could certainly boost the debate. The two new elements in the discussion could be the relative effects of both the iodinated compounds and the choice of the optimal energy to increase the enhancement ratios.

Other clinical applications could be found by associating a monochromatic photon source with a heavy intratumoral element. The ideal radioisotope would be one able to optimise interactions with the targeted heavy atom. Of course, this limits the number of (emitter-receptor) couples to be considered, but opens the way to new source concepts (Karnas et al, 2001b). Samarium sources, which emit monochromatic $40 \mathrm{keV} \gamma$ photons, could be used, for instance, in association with stable iodine (Fairchild et al, 1987; Laster et al, 1992). Energy deposited by ${ }^{125} \mathrm{I}$ seeds during prostate brachytherapy treatment could be enhanced by silver compounds (Young et al, 1999) or other contrast agents like iodine, gadolinium or lutetium as well (Norman et al, 2002).

However, the synchrotron tool appears to be the most useful one for optimizing such a concept of bimodal radiotherapy and monochromatic synchrotron radiotherapy, which exhibits promising in vivo results (Adam et al, 2003). This concept is hence proposed as a promising technique for optimally increasing the differential effect between healthy and cancerous tissue irradiation.

\section{ACKNOWLEDGEMENTS}

This work was supported by research grants from the Association pour la Recherche contre le Cancer and from the Ligue Nationale contre le Cancer. Stéphanie Corde was supported by a fellowship 
from Région Rhône-Alpes and from Fondation pour la Recherche Médicale. All experiments were made owing to the ESRF beam shift allocations on ID17. We are gratefully indebted to ESRF medical beamline staff for their scientific and technical help.

\section{REFERENCES}

Adam JF, Elleaume H, Joubert A, Biston MC, Charvet AM, Balosso J, Le Bas JF, Estève F (2003) Synchrotron Radiation therapy of malignant brain glioma loaded with an iodinated contrast agent: first trial on rats bearing F98 gliomas. Int J Radiat Oncol Biol Phys 57: 1413-1426

Adams FH, Norman A, Mello RS, Bass D (1977) Effect of radiation and contrast media on chromosomes. Preliminary report. Radiology 124: $823-826$

Barth RF, Soloway AH, Fairchild RG (1990) Boron neutron capture therapy for cancer. Sci Am 263: $100-107$

Biston MC, Corde S, Camus E, Marti-Battle R, Estève F, Balosso J (2003) An objective method to measure cell survival by computed-assisted image processing using numeric images of Petri dishes. Phys Med Biol 48: $1551-1563$

Brachman DG, Beckett M, Graves D, Haraf D, Vokes E, Weichselbaum RR (1993) p53 mutation does not correlate with radiosensitivity in 24 head and neck cancer cell lines. Cancer Res 53: 3667-3669

Callisen HH, Norman A, Adams FH (1979) Absorbed dose in the presence of contrast agents during pediatric cardiac catheterization. Med Phys 6: 504-509

Coderre JA, Chanana AD, Joel DD, Elowitz EH, Micca PL, Nawrocky MM, Chadha M, Gebbers JO, Shady M, Peress NS, Slatkin DN (1998) Biodistribution of boronophenylalanine in patients with glioblastoma multiforme: boron concentration correlates with tumor cellularity. Radiat Res 149: $163-170$

Commerford SL, Bond VP, Conkrite EP, Reincke U (1980) Radiotoxicity of intranuclear ${ }^{125} \mathrm{I}$ atoms not bound to DNA. Int J Radiat Biol 37: $547-554$

Corde S, Biston MC, Elleaume H, Estève F, Charvet AM, Joubert A, Ducros V, Bohic S, Simionovici A, Brochard T, Nemoz C, Renier M, Troprès I, Fiedler S, Bravin A, Thomlinson W, Le Bas JF, Balosso J (2002) Lack of cell death enhancement after irradiation with monochromatic synchrotron $\mathrm{X}$ rays at the K-shell edge of platinum incorporated in living SQ20B human cells as cis-diamminedichloroplatinum (II). Radiat Res 158: $763-770$

Dawson P, Penhaligon M, Smith E, Saunders J (1987) Iodinated contrast agents as 'radiosensitizers'. Br J Radiol 60: 201-203

Elleaume H, Charvet AM, Berkvens P, Berruyer G, Brochard T, Dabin Y, Dominguez MC, Draperi A, Fiedler S, Goujon G, Le Duc G, Mattenet M, Nemoz C, Perez M, Renier M, Schulze C, Spanne P, Suortti P, Thomlinson W, Estève F, Bertrand B, Le Bas JF (1999) Instrumentation of the ESRF Medical Imaging Facility. Nucl Instrum Methods A 428: $513-527$

Elleaume H, Charvet AM, Corde S, Estève F, Le Bas JF (2002) Performance of computed tomography for contrast agent concentration measurements with monochromatic X-ray beams: comparison of K-edge versus temporal subtraction. Phys Med Biol 45: 3369-3385

Elleaume H, Charvet AM, Le Duc G, Estève F, Bertrand B, Corde S, Farion R, Lefaix JL, Leplat JJ, Berkvens P, Berruyer G, Brochard T, Dabin Y, Draperi A, Fiedler S, Nemoz C, Perez M, Renier M, Suortti P, Thomlinson $\mathrm{W}$, Le Bas JF (2000b) In vivo K-edge imaging with synchrotron radiation. Cell Mol Biol 46: $1065-1075$

Elleaume H, Fiedler S, Estève F, Bertrand B, Charvet AM, Berkvens P, Berruyer G, Brochard T, Le Duc G, Nemoz C, Renier M, Suortti P, Thomlinson W, Le Bas JF (2000a) First human transvenous coronorary angiography at the European synchrotron radiation facility. Phys Med Biol 45: L39-L43

Epstein AH, Cook JA, Goffman T, Glatstein E (1992) Tumour radiosensitization with the halogenated pyrimidines $5^{\prime}$-bromo- and 5'-iododeoxyuridine. Br J Radiol 24: 209-214

Estève F, Corde S, Elleaume H, Adam JF, Joubert A, Charvet AM, Biston MC, Balosso J, Le Bas JF (2002) Enhanced radio sensitivity with iodinated contrast agents using monochromatic synchrotron X-rays on human cancerous cells. Acad Radiol 9: S540-S543

Fairchild RG, Bond VP (1984) Photon activation therapy. Strahlentherapie 160: $758-763$

Fairchild RG, Brill AB, Ettinger KV (1982) Radiation enhancement with iodinated deoxyuridine. Invest Radiol 17: 407-416
Fairchild RG, Kalef-Ezra J, Packer S, Wielopolski L, Laster BH, Robertson JS, Mausner L, Kanellitsas C (1987) Samarium-145: a new brachytherapy source. Phys Med Biol 32: $847-858$

Fairchild RG, Laster BH, Commerford SL, Furcinitti FS, Sylvester B, Gabe D, Popenoe E, Foster S (1985) Photon activation therapy with ${ }^{127} \mathrm{I}$ deoxyuridine: measurement of dose enhancement in cultured mammalian cells. In Workshop on Photon Activation Therapy, Brookhaven National Laboratory Report BNL 51997, pp 1-16, Upton, NY

Faraggi M, Gardin I, deLabriolle-Vaylet C, Moretti JL, Bok BD (1994) The influence of tracer localization on the electron dose rate delivered to the cell nucleus. J Nucl Med 35: $113-119$

Hieda K, Hirono T, Azami A, Suzuki M, Furusawa Y, Maezawa H, Usami N, Yokoya A, Kobayashi K (1996) Single- and double-strand breaks in pBR322 plasmid DNA by monochromatic X-Rays on and off the K-absorption peak of phosphorus. Int J Radiat Biol 70: 437-445

Hubbell JH, Seltzer SM (1997) Tables of X-Ray Mass Attenuation Coefficients and Mass Energy-Absorption Coefficients (version 1.02) [Online]. Available:. http://physics.nist.gov/xaamdi. Gaithersburg, MD: National Institute of Standards and Technology

Humm J (1988a) Therapy by photon activation? Nature 336: 710-711

Humm JL, Charlton DE (1988b) Double strand breakage in DNA produced by the photoelectric interaction with incorporated 'cold' murine. In DNA Damage by Auger Electron Emitters, Baverstock K, Charlton D (eds). pp $111-122$, London: Taylor \& Francis

Iliakis G, Kurtzman S (1989) Keynote address: application of non-hypoxic cell sensitizers in radiobiology and radiotherapy: rationale and future prospects. Int J Radiat Oncol Biol Phys 16: 1235-1241

Iwamoto KS, Cochran ST, Winter J, Holburt E, Higashida RT, Norman A (1987) Radiation dose enhancement therapy with iodine in rabbit VX-2 brain tumors. Radiother Oncol 8: $161-170$

Iwamoto KS, Norman A, Kagan AR, Wollin M, Olch A, Bellotti J, Ingram M, Skillen RG (1990) The CT scanner as a therapy machine. Radiother Oncol 19: $337-343$

Karnas SJ, Avvakumov N, Yu E, Battista JJ (2001b) Operational characteristics of a prototype X-ray needle device. Phys Med Biol 46: $97-106$

Karnas SJ, Moiseenko VV, Yu E, Truong P, Battista JJ (2001a) Monte Carlo simulations and measurement of DNA damage from X-ray-triggered auger cascades in iododeoxyuridine (IUdR). Radiat Environ Biophys 40: $199-206$

Karnas SJ, Yu E, McGarry RC, Battista JJ (1999) Optimal photon energies for IUdR K-edge radiosensitization with filtered X-ray and radioisotope sources. Phys Med Biol 44: 2537-2549

Laster BH, Thomlinson WC, Fairchild RG (1993) Photon activation of iododeoxyuridine: biological efficacy of Auger electrons. Radiat Res 133: $219-224$

Laster BH, Thomlinson WC, Kalef-Ezra J, Benary V, Popenoe EA, Bond VP, Gordon C, Warkentien L, Gmür N, Lazarz N, Fairchild RG (1992) The biological efficacy of induced Auger cascades: comparison of iodine and bromine as target atoms. In Biophysical Aspects of Auger Processes, Howell RW, Narra VR, Sastry KSR, Rao DV (eds). pp 91 - 105, Woodbury NY: American Institute of physics

Le Duc G, Corde S, Elleaume H, Estève F, Charvet AM, Brochard T, Fiedler S, Collomb A, Le Bas JF (2000) Feasibility of synchrotron radiation computed tomography on rats bearing glioma after iodine or gadolinium injection. Eur Radiol 10: 1487-1492

Matsudaira H, Ueno AM, Furuno I (1980) Iodine contrast medium sensitizes cultured mammalian cells to X-rays but not to gamma rays. Radiat Res 84: 144-148

Mesa AV, Norman A, Solberg TD, Demarco JJ, Smathers JB (1999) Dose distributions using kilovoltage $\mathrm{X}$-rays and dose enhancement from iodine contrast agents. Phys Med Biol 44: 1955-1968

Miller RW, DeGraff W, Kinsella TJ, Mitchell JB (1987a) Evaluation of incorporated iododeoxyuridine cellular radiosensitization by photon activation therapy. Int J Radiat Oncol Biol Phys 13: 1193-1197

Miller RW, DeGraff W, Mitchell JB, Kinsella TJ (1987b) Photon activation therapy (PAT) [letter]. Int J Radiat Oncol Biol Phys 13: 1429 
Nath R, Bongiorni P, Rockwell S (1987) Enhancement of IUdR radiosensitization by low energy photons. Int J Radiat Oncol Biol Phys 13: $1071-1079$

Nath R, Bongiorni P, Rossi PI, Rockwell S (1990) Enhanced IUdR radiosensitization by ${ }^{241} \mathrm{Am}$ photons relative to ${ }^{226} \mathrm{Ra}$ and ${ }^{125} \mathrm{I}$ photons at $0,72 \mathrm{~Gy} / \mathrm{h}$. Int J Radiat Oncol Biol Phys 18: 1377-1385

Norman A, Adams FH, Riley RF (1978) Cytogenetic effects of contrast media and triiodobenzoic acid derivatives in human lymphocytes. Radiology 129: 199-203

Norman A, Cochran ST, Sayre JW (2001) Meta-analysis of increases in micronuclei in peripheral blood lymphocytes after angiography or excretory urography. Radiat Res 155: $740-743$

Norman A, Mesa AV, Solberg TD, Cochran ST (2002) Contrast-enhanced brachytherapy for prostate cancer. Acad Radiol 9: S182-S184

Pomplun E, Terrissol M (1994) Low-energy electrons inside active DNA models: a tool to elucidate the radiation action mechanisms. Radiat Environ Biophys 33: 279-292

Robar JL, Riccio SA, Martin MA (2002) Tumour dose enhancement using modified megavoltage photon beams and contrast media. Phys Med Biol 47: $2433-2449$

Rose JH, Norman A, Ingram M, Aoki C, Solberg T, Mesa A (1999) First radiotherapy of human metastatic brain tumors delivered by a computerized tomography scanner (CTRx). Int J Radiat Oncol Biol Phys 45: $1127-1132$

Shinohara K, Nakano H, Ohara H (1996) Detection of Auger enhancement induced in HeLa cells with iododeoxyuridine and irradiated with $150 \mathrm{kV}$ X-Rays: effects of cysteamine and dimethylsulfoxide. Acta Oncol 35: $869-875$

Solberg TD, DeMarco JJ, Cagnon C, Smathers JB, Norman A (1995) Dosimetry and treatment planning for X-Ray phototherapy. Med Phys 22: 968

Solberg TD, Iwamoto KS, Norman A (1992a) Calculation of radiation dose enhancement factors for dose enhancement therapy of brain tumours. Phys Med Biol 37: 439-443

Solberg TD, Wallace RE, Norman A, Iwamoto KS (1992b) Synchrotron radiation for dose enhancement therapy of brain tumors (Abstr), Proceedings of the 40th Annual Meeting of the Radiation Research Society, p 55

Soloway AH, Barth RF, Rong FG, Wyzlick IM, Tjarks W, Anissuzzaman AKM, Lunato AJ, Ives DH (1994) Design of boron compounds for neutron capture therapy. In Hadrontherapy in Oncology, Amaldi U, Larsson B (eds). pp 550-554, Amsterdam: Elsevier Science
Suortti P, Fiedler S, Bravin A, Brochard T, Mattenet M, Renier M, Spanne P, Thomlinson W, Charvet AM, Elleaume H, Schulze-Briese C, Thompson AC (2000) Fixed-exit monochromator for computed tomography with synchrotron radiation at energies 18 to $90 \mathrm{keV}$. J Synchrotron Radiat 7: $340-347$

Thomlinson W, Berkvens P, Berruyer G, Bertrand B, Blattmann H, BrauerKrisch E, Brochard T, Charvet AM, Corde S, Dimichiel M, Elleaume H, Estève F, Fiedler S, Laissue JA, Le Bas JE, Le Duc G, Lyubimova N, Nemoz C, Renier M, Slatkin DN, Spanne P, Suortti P (2000) Research at the European Synchrotron Radiation Facility Medical Beamline. Cell Mol Biol 46: 1043 - 1053

Tisljar-Lentulis G, Feinendegen LE (1977) The bromine enhancement ratio in mammalian cells in vitro and experimental mouse tumors. Curr Top Radiat Res Quart 12: 526-536

Tisljar-Lentulis G, Feinendegen LE, Bond VP (1973) Biological radiation effects of inclusion of moderately heavy nuclei into the tissue and use of soft roentgen rays. Strahlentherapie 145: 656-662

van Dieren EB, Plaizier M, van Lingen A, Roos JC, Barendsen GW, Teule GJ (1996) Absorbed dose distribution of the Auger emitters ${ }^{67} \mathrm{Ga}$ and ${ }^{125} \mathrm{I}$ and the beta-emitters ${ }^{67} \mathrm{Cu},{ }^{90} \mathrm{Y},{ }^{131} \mathrm{I}$ and ${ }^{186} \mathrm{Re}$ as a function of tumor size, uptake and intracellular distribution. Int J Radiat Oncol Biol Phys 36: $197-204$

Verbakel WFAR, Stecher-Rasmussen F (2001) On-line reconstruction of low boron concentrations by in vivo $\gamma$-ray spectroscopy for BNCT. Phys Med Biol 46: $687-701$

Wang Y, Iliakis G (1992) Effects of $5^{\prime}$-iododeoxyuridine on the repair of radiation induced potentially lethal damage interfase chromatin breaks and DNA double strand breaks in Chenese hamster ovary cells. Int $J$ Radiat Oncol Biol Phys 23: $353-360$

Wang Y, Pantelias GE, Iliakis G (1994) Mechanism of radiosensitization by halogenated pyrimidines: the contribution of excell DNA and chromosome damage in BrdU radiosensitization may be minimal in plateauphase cells. Int J Radiat Biol 66: $133-142$

Weichselbaum RR, Dahlberg WK, Beckett WK, Karrison T, Miller D, Clark J, Ervin TJ (1986) Radiation-resistant and repair-proficient human tumor cells may be associated with radiotherapy failure in head- and neck- cancer patients. Proc Natl Acad Sci USA 83: $2684-2688$

Young LA, Phillips MH, Nelson JA (1999) Validation of K-edge ${ }^{125} \mathrm{I}$ brachytherapy enhancement with silver compounds. Phys Med Biol 44: $1921-1935$ 